\title{
Multiple P2Y receptors couple to calcium-dependent, chloride channels in smooth muscle cells of the rat pulmonary artery Krongkarn Chootip ${ }^{1,2}$, Alison M Gurney ${ }^{1}$ and Charles Kennedy*1
}

Address: ${ }^{1}$ Department of Physiology and Pharmacology, University of Strathclyde, Strathclyde Institute for Biomedical Sciences, John Arbuthnott Building, 27 Taylor Street, Glasgow G4 ONR, UK and 2Department of Physiology, Faculty of Medical Science, Naresuan University, Phitsanulok 65000, Thailand

Email: Krongkarn Chootip - krongkarn.chootip@strath.ac.uk; Alison M Gurney - a.m.gurney@strath.ac.uk;

Charles Kennedy* - c.kennedy@strath.ac.uk

* Corresponding author

Published: 26 October 2005

Respiratory Research 2005, 6:124 doi:10.1 186//465-992I-6-124

This article is available from: http://respiratory-research.com/content/6/1/124

(c) 2005 Chootip et al; licensee BioMed Central Ltd.

This is an Open Access article distributed under the terms of the Creative Commons Attribution License (http://creativecommons.org/licenses/by/2.0), which permits unrestricted use, distribution, and reproduction in any medium, provided the original work is properly cited.

\begin{abstract}
Background: Uridine 5'-triphosphate (UTP) and uridine 5'-diphosphate (UDP) act via P2Y receptors to evoke contraction of rat pulmonary arteries, whilst adenosine 5'-triphosphate (ATP) acts via P2X and P2Y receptors. Pharmacological characterisation of these receptors in intact arteries is complicated by release and extracellular metabolism of nucleotides, so the aim of this study was to characterise the $\mathrm{P} 2 \mathrm{Y}$ receptors under conditions that minimise these problems.
\end{abstract}

Methods: The perforated-patch clamp technique was used to record the $\mathrm{Ca}^{2+}$-dependent, $\mathrm{Cl}^{-}$ current $\left(\mathrm{I}_{\mathrm{Cl}, \mathrm{C}_{\mathrm{a}}}\right)$ activated by P2Y receptor agonists in acutely dissociated smooth muscle cells of rat small (SPA) and large (LPA) intrapulmonary arteries, held at $-50 \mathrm{mV}$. Contractions to ATP were measured in isolated muscle rings. Data were compared by Student's $t$ test or one way ANOVA.

Results: ATP, UTP and UDP (10-4 M) evoked oscillating, inward currents (peak = 13-727 pA) in $71-93 \%$ of cells. The first current was usually the largest and in the SPA the response to ATP was significantly greater than those to UTP or UDP $(P<0.05)$. Subsequent currents tended to decrease in amplitude, with a variable time-course, to a level that was significantly smaller for ATP $(P<0.05)$, UTP $(P<0.00 I)$ and UDP $(P<0.05)$ in the SPA. The frequency of oscillations was similar for each agonist $\left(\right.$ mean $\left.\approx 6-11 . \mathrm{min}^{-1}\right)$ and changed little during agonist application. The non-selective P2 receptor antagonist suramin $\left(10^{-4} \mathrm{M}\right)$ abolished currents evoked by ATP in SPA $(n=4)$ and LPA $(n$ $=4)$, but pyridoxalphosphate-6-azophenyl-2',4'-disulphonic acid (PPADS) (I0-4M), also a nonselective P2 antagonist, had no effect $(n=4,5$ respectively). Currents elicited by UTP $(n=37)$ or UDP $(n=14)$ were unaffected by either antagonist. Contractions of SPA evoked by ATP were partially inhibited by PPADS $(n=4)$ and abolished by suramin $(n=5)$. Both antagonists abolished the contractions in LPA.

Conclusion: At least two P2Y subtypes couple to $\mathrm{I}_{\mathrm{Cl}, \mathrm{Ca}}$ in smooth muscle cells of rat SPA and LPA, with no apparent regional variation in their distribution. The suramin-sensitive, PPADS-resistant site activated by ATP most resembles the P2Y 11 receptor. However, the suramin- and PPADSinsensitive receptor activated by UTP and UDP does not correspond to any of the known P2Y subtypes. These receptors likely play a significant role in nucleotide-induced vasoconstriction. 


\section{Background}

Uridine 5'-triphosphate (UTP) and uridine 5'-diphosphate (UDP) act via P2Y receptors, whilst adenosine 5'-triphosphate (ATP) acts via P2X as well as P2Y receptors, to modulate vascular tone [1-3]. P2X receptors are ligandgated cation channels and the ability of the $\mathrm{P} 2 \mathrm{X}_{1}$ subtype to mediate rapid, transient inward currents in pulmonary artery smooth muscle cells $[4,5]$ and induce constriction of the pulmonary vasculature (see [6] and references therein) has been characterised in some depth. P2Y receptors are G protein-coupled receptors and P2Y agonists act at smooth muscle receptors to evoke vasoconstriction in the rat perfused lung at resting tone, but induce vasodilation via endothelial receptors if muscle tone is first raised [7-10]. Similarly, P2Y agonists are contractile at resting tone and relaxant at raised tone in isolated branches of rat intrapulmonary arteries [11-13]. Compared with P2X receptors much less is known about which of the eight mammalian P2Y subtypes (P2Y $1,2,4,6,11,12,13,14)[14,15]$ are expressed in pulmonary vascular smooth muscle or about the signalling pathways through which they act.

In a previous study [6] we showed that UTP and UDP both act via two P2Y receptors to evoke contraction of rat isolated pulmonary arteries. For each agonist one site was insensitive to the antagonists suramin and pyridoxalphosphate-6-azophenyl-2', 4'-disulphonic acid (PPADS), whilst the other was inhibited by suramin, but not PPADS. UTP is a potent agonist at the $\mathrm{P}_{2} \mathrm{Y}_{2}$ and $\mathrm{P} 2 \mathrm{Y}_{4}$ receptors and a weaker agonist at the $\mathrm{P}_{2} \mathrm{Y}_{6}$ subtype $[16,17]$. Of these three receptors, only the $\mathrm{P}_{2} \mathrm{Y}_{2}$ is suramin-sensitive and PPADS-insensitive [18], so this is likely to be one of the sites of action of UTP. The molecular identity of the suramin-and PPADS-insensitive site of action of UTP is unclear as the $\mathrm{P}_{2} \mathrm{Y}_{4}$ and $\mathrm{P}_{2} \mathrm{Y}_{6}$ subtypes are both reported to be antagonised by PPADS, but not suramin [18-20]. UDP is a potent agonist at the $\mathrm{P}^{2} \mathrm{Y}_{6}$ receptor only $[16,17]$. mRNA for this subtype and suramin-insensitive contractions to UDP in pulmonary arteries have been demonstrated [12], but the lack of effect of PPADS against the contractions evoked by UDP in our previous study are inconsistent with the $\mathrm{P}_{2} \mathrm{Y}_{6}$ receptor.

A number of factors that can complicate the characterisation of P2Y receptors may have prevented the clear identification of the P2Y receptors mediating the contractions seen in previous studies. These include the release of nucleotides from cells, their breakdown by ecto-nucleotidases and their bioconversion by ecto-nucleoside diphosphokinase (eNDPK) [16,21-24]. Thus, as well as a direct action at the $\mathrm{P}_{2} \mathrm{Y}_{6}$ receptor, UTP can also act indirectly, after dephosphorylation to UDP. Likewise, UDP can be converted to UTP by eNDPK and so act indirectly at P2 ${ }_{2}$ and $\mathrm{P}_{2} \mathrm{Y}_{4}$ receptors. At present, potent and selective inhib- itors of the ecto-enzymes are not available, but one way to minimise these metabolic problems is to apply the agonists to rapidly perfused, dissociated cells.

The aim of the present study was to extend the pharamacological characterisation of the P2Y receptors mediating pulmonary vasoconstriction, in conditions that minimise the influence of the release and extracellular metabolism of nucleotides. We used the perforated-patch clamp technique to record the $\mathrm{Ca}^{2+}$-dependent, $\mathrm{Cl}^{-}$current $\left(\mathrm{I}_{\mathrm{Cl}, \mathrm{Ca}}\right)$ induced by nucleotides in single, acutely dissociated pulmonary artery smooth muscle cells $[4,5]$. The pulmonary vascular bed has well characterised regional differences in receptor and ion channel distribution, including $\mathrm{I}_{\mathrm{Cl}, \mathrm{Ca}}$ $[8,25]$, so the responses of cells isolated from large and small pulmonary arteries were compared. In addition to UTP and UDP, we also applied ATP, an agonist at the P2Y $1,2,4,11 \& 12$ subtypes [14] and determined the ability of the P2 antagonists suramin and PPADS to inhibit the responses evoked by each of the agonists. We found that at least two $\mathrm{P} 2 \mathrm{Y}$ subtypes couple to $\mathrm{I}_{\mathrm{Cl}_{1} \mathrm{Ca}^{\prime}}$ with no apparent regional variation in their distribution. The suraminsensitive, PPADS-resistant site activated by ATP most resembles the $\mathrm{P}_{2} \mathrm{Y}_{11}$ receptor. However, the suramin- and PPADS-insensitive receptor activated by UTP and UDP does not correspond to any of the known P2Y subtypes.

\section{Methods \\ Isolated cell preparation}

Male Sprague-Dawley rats (150 - $250 \mathrm{~g})$ were killed by the approved Schedule 1 method of cervical dislocation and exsanguination. After thoracotomy, the heart and lungs were removed en bloc, the lungs separated and small (SPA, 200-500 $\mu \mathrm{m}$ id) and large (LPA, $1.0-1.5 \mathrm{~mm}$ id) intrapulmonary arteries dissected out. The arteries were cut open longitudinally and strips of smooth muscle bathed in a dissociation medium (DM) composed of $(\mathrm{mM}) ; \mathrm{NaCl}$ $110 ; \mathrm{KCl} 5 ; \mathrm{KH}_{2} \mathrm{PO}_{4} 0.5 ; \mathrm{NaH}_{2} \mathrm{PO}_{4} 0.5 ; \mathrm{NaHCO}_{3} 10 ; \mathrm{N}$-[2hydroxyethyl]piperazine-N'-[2-ethane-sulfonic acid] (HEPES)10; phenol red 0.03; taurine 10; ethylenediaminetetraacetic acid (EDTA) $0.5 ; \mathrm{MgCl}_{2} 2$; glucose 10 and $\mathrm{CaCl}_{2} 0.16$, titrated to $\mathrm{pH} 7.0$ with $\mathrm{KOH}$. After incubation in DM containing $0.6-0.8 \mathrm{mg}^{-\mathrm{ml}^{-1}}$ papain, $0.04 \%$ BSA and $0.4 \mathrm{mM}$ dithiothreitol at $37^{\circ} \mathrm{C}(15 \mathrm{~min}$ for LPA, 10 min for SPA), collagenase ( $0.6-0.8$ mg. $\mathrm{ml}^{-1}$; type IA) was added and the tissues incubated for a further 10 (LPA) or 5 (SPA) min. Cells were then dispersed by mild trituration in enzyme-free solution and used within 7 hours.

\section{Electrophysiological recording}

Cells were placed in a $50 \mu \mathrm{l}$ chamber and superfused at room temperature with physiological salt solution (PSS) composed of (mM): $\mathrm{NaCl} 122 ; \mathrm{KCl} 5 ; \mathrm{HEPES} 10 ; \mathrm{KH}_{2} \mathrm{PO}_{4}$ $0.5 ; \mathrm{NaH}_{2} \mathrm{PO}_{4} 0.5 ; \mathrm{MgCl}_{2} 1$; glucose $11 ; \mathrm{CaCl}_{2} 1.8$; titrated to $\mathrm{pH} 7.3$ with $\mathrm{NaOH}$. Electrophysiological responses of 
isolated smooth muscle cells were studied in the wholecell, perforated-patch mode with amphotericin B (150 $\mu \mathrm{g} . \mathrm{ml}^{-1}$ ) added to a pipette solution of the following composition (mM): KCl 125; $\mathrm{MgCl}_{2} 4$; HEPES 10; ethylene glycol-bis(2-aminoethylether)-N, $, \mathrm{N}^{\prime}, \mathrm{N}^{\prime}$-tetraacetic acid (EGTA) 0.02 , titrated to $\mathrm{pH} 7.3$ with $\mathrm{KOH}$. Pipette resistance was 4-8 M $\Omega$. The cells were voltage-clamped at -50 $\mathrm{mV}$ using an Axopatch 200A amplifier (Axon Instruments). Data were recorded and analysed with a personal computer interfaced with a Digidata $1200 \mathrm{~A} / \mathrm{D}$ converter (Axon Instruments) using Axotape and pClamp (V5) software (Axon Instruments). Current responses to $-10 \mathrm{mV}$ hyperpolarizing steps were used to measure cell capacitance.

We have reported previously that $10^{-4} \mathrm{M}$ ATP, UTP and UDP each evoked pronounced contractions of rat isolated SPA and LPA and that $10^{-4} \mathrm{M}$ suramin and PPADS produced maximum inhibition of these responses [6]. Therefore, this concentration of these drugs was used here. All were applied to the cells using a gravity-feed perfusion system, for which the time for complete solution exchange was less than $2 \mathrm{~s}$. Only one agonist was applied to each cell. P2Y receptor-mediated contractions develop slowly and take 5-10 min to reach a steady-state plateau, therefore, in most cases the agonists were applied to the cells for 5 min or more.

\section{Electrophysiological analysis}

The rat pulmonary artery is a relatively short vessel, with only a thin layer of smooth muscle cells. Enzymatic dissociation produces a lower yield of cells that are smaller and often less robust than those from systemic blood vessels. Consequently, although oscillating inward currents were observed in response to $\mathrm{P} 2 \mathrm{Y}$ receptor agonists in the majority of cells studied, quantitative analysis was hampered by the short period of time that many cells could be maintained in the perforated-patch configuration or by the disappearance of the response during the recording. Quantitative analysis was applied only to cells that could be held for $5 \mathrm{~min}$ or more and in which the oscillating currents lasted more than $4 \mathrm{~min}$. In these cells the following parameters were measured: a) the peak amplitude of each current (pA), which was normalised against the cell capacitance $(\mathrm{pF})$ to control for variations in cell size; $b$ ) the rise time (ms) of the current at each oscillation from baseline holding current to peak; c) the width of each oscillation $(\mathrm{ms})$ at the point where it reached $50 \%$ of its peak amplitude. For each, the average value during successive $30 \mathrm{~s}$ intervals over a 4 min period was calculated and compared. Finally, the frequency of oscillations (peak. $\mathrm{min}^{-1}$ ) was measured as the number of transient currents occurring during successive $1 \mathrm{~min}$ intervals over a $4 \mathrm{~min}$ period.
To investigate the effects of P2 receptor antagonists on the currents, some cells were preincubated with antagonist for 5 min before adding an agonist, but in most cases an agonist was applied for $2 \mathrm{~min}$ and then suramin or PPADS were co-applied for a further 2-3 min. The current amplitude and frequency were measured and average values compared for the 1 min periods immediately before and after antagonist addition. The data were compared with control cells where agonist alone was added and the currents measured over the same time course.

\section{Tension recording}

Rat SPA and LPA were dissected out as described above, cut into rings $5 \mathrm{~mm}$ long and mounted horizontally in 1 $\mathrm{ml}$ baths on a pair of intraluminal wires [6]. Tissues were allowed to equilibrate under a resting tension of $0.5 \mathrm{~g}$ (SPA) and $1.0 \mathrm{~g}$ (LPA) for $60 \mathrm{~min}$ at $37^{\circ} \mathrm{C}$ in PSS. Tension was recorded with Grass FT03 isometric force transducers connected to a MacLab/4e system, using Chart 3.3 software (AD Instruments). Cumulative concentrationresponse curves to ATP were obtained in rings in the absence of antagonist (control) or in the presence of a single concentration $\left(3 \times 10^{-5}, 10^{-4}\right.$ or $\left.3 \times 10^{-4} \mathrm{M}\right)$ of suramin or PPADS. Contractions generally took 1-4 min to reach a plateau and are expressed as a percentage of the contraction induced in the same preparation by $4 \times 10^{-2} \mathrm{M} \mathrm{KCl}$, which was applied by replacement of the PSS solution with PSS in which the $\mathrm{KCl}$ concentration was raised by equimolar substitution for $\mathrm{NaCl}$.

\section{Data analysis}

Values in the text and figures refer to mean \pm S.E.M.. Data were compared by paired and unpaired t-tests, or one-way analysis of variance and Tukey's comparison as appropriate. Differences were considered significant when $\mathrm{P}<$ 0.05 .

\section{Drugs and solutions}

ATP (magnesium salt), UDP (sodium salt), UTP (sodium salt), suramin hexasodium and PPADS tetrasodium (Sigma/RBI, UK) were dissolved in deionised water as 100 $\mathrm{mM}$ stock solutions and diluted in PSS before application to the cells.

\section{Results}

P2Y receptor agonists induce oscillating inward currents ATP, UTP and UDP $\left(10^{-4} \mathrm{M}\right)$ each evoked inward currents (peak amplitude $=13-727 \mathrm{pA})$ in most SPA $(\mathrm{n}=118)$ and LPA $(\mathrm{n}=117)$ smooth muscle cells held at $-50 \mathrm{mV}$ (ATP-91\%/88\%, UTP-91\%/93\%, UDP-71\%/81\%, SPA/ LPA respectively). Outward currents or no response were evoked in the remaining cells, which were not studied further. In most cells the inward currents activated in an oscillating manner (Figure 1). The first current was usually the largest and subsequent currents decreased in 
a.

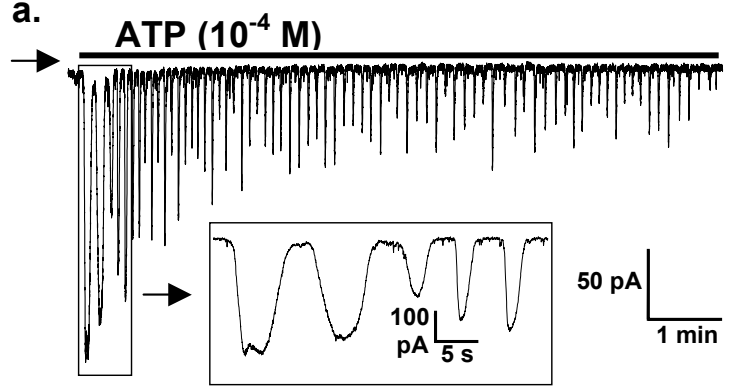

b.
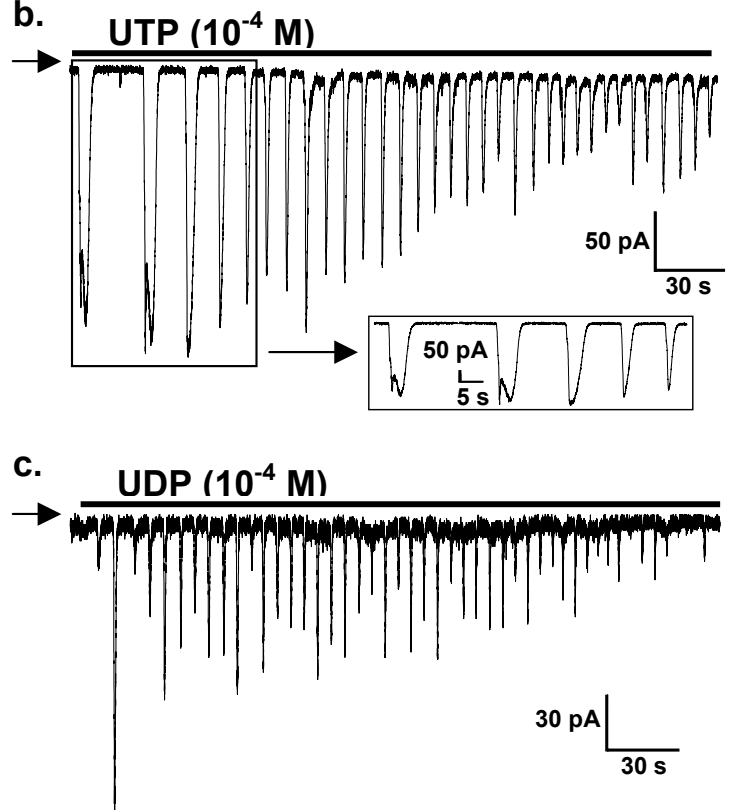

Figure I

Oscillating currents induced by $\mathrm{P} 2 \mathrm{Y}$ receptor agonists. (a) ATP, (b) UTP and (c) UDP (all 10-4 M), added as indicated by the horizontal bars, evoked oscillating inward currents in smooth muscle cells isolated from SPA (a \& c) and LPA (b) and voltage-clamped at $-50 \mathrm{mV}$. The insets show W-shape currents induced by (a) ATP and (b) UTP. The arrow on the left-hand side of each trace indicates zero holding current.

amplitude, with a variable time-course. The peak of the first current appeared to be larger for ATP than UTP or UDP (Figure 2), but this was significant only in the SPA (P $<0.05$ ). For each agonist there was no significant difference in the amplitude of the first response between the small and large vessels. The initial current often had a "Wshaped" profile (Figure 1), but in most cells $(85 \%)$ the biphasic profile disappeared by the second, third or

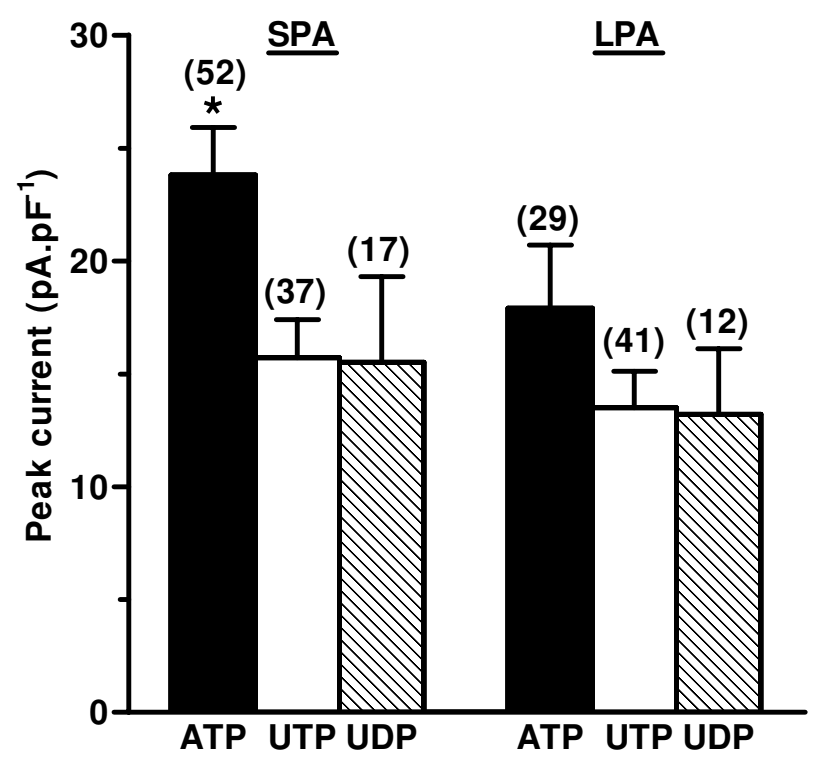

Figure 2

Amplitude of the first inward current induced by P2Y receptor agonists. The mean \pm s.e.mean of the peak amplitude of the initial inward currents evoked by $10^{-4} \mathrm{M}$ ATP, UTP and UDP in SPA and LPA isolated smooth muscle cells, voltage-clamped at $-50 \mathrm{mV}$, are shown. The number of cells for each is indicated in parentheses. ${ }^{*} \mathrm{P}<0.05$ for responses to ATP versus UTP and UDP in SPA.

fourth oscillation, such that subsequent currents were monophasic. ATP, UTP and UDP each evoked this profile of responses in a similar proportion of cells.

\section{Quantitative analysis of oscillating currents}

The decrease in the amplitude of the oscillating currents during agonist application complicated the quantification of the effects of P2Y antagonists, so it was necessary to first quantify the time-course of the currents. In order to be able to study the effects of both an agonist and antagonist on the same cell, the analysis was limited to a subpopulation of cells that were maintained under voltage-clamp for more than $5 \mathrm{~min}$ and in which the oscillating currents lasted for 4 min or more.

In both SPA (Figure 3a) and LPA (not shown), the amplitude of the oscillating currents tended to decrease over successive $30 \mathrm{~s}$ intervals, particularly within the first 2 min, and this was significant for ATP $(\mathrm{P}<0.05)$, UTP $(\mathrm{P}<$ $0.01)$ and UDP $(\mathrm{P}<0.05)$ in the SPA. The oscillations induced by ATP, UTP and UDP had similar frequencies (mean $\approx 6-11 \cdot \mathrm{min}^{-1}$ ), both in SPA (Figure 3b) and LPA (not shown) and showed no significant change over 4 

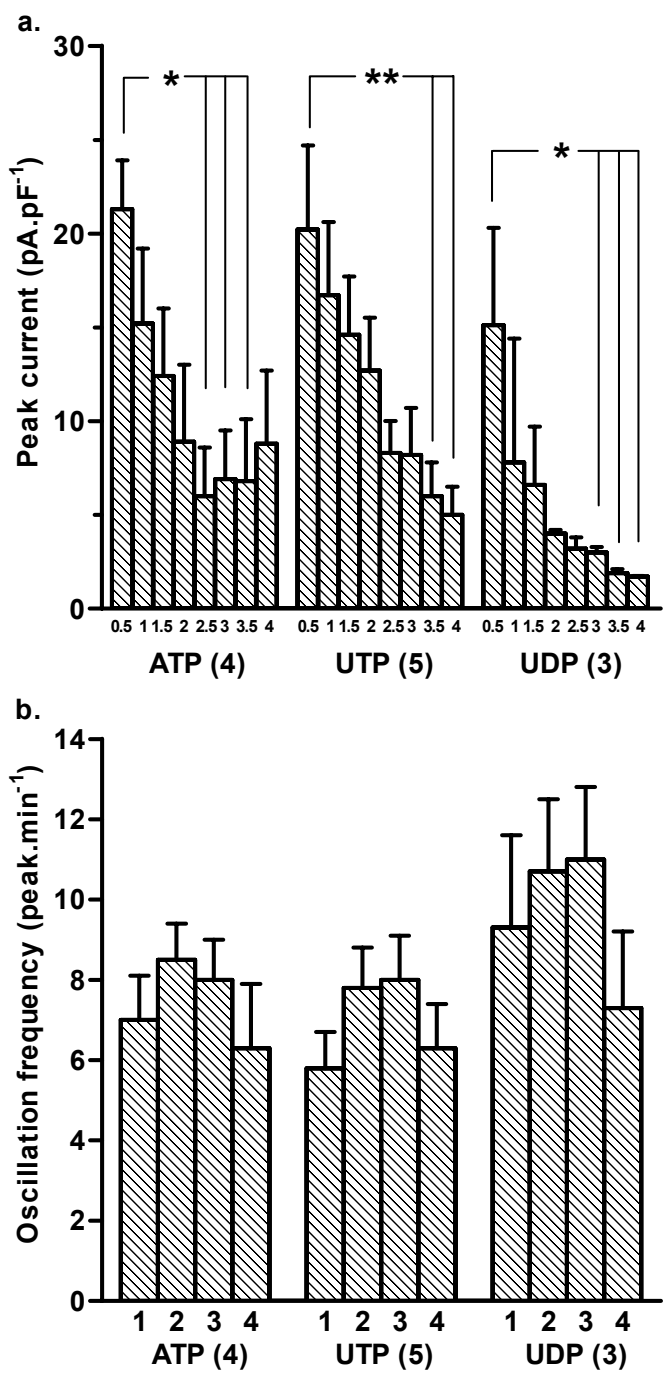

Figure 3

The amplitude and frequency of oscillating currents induced by $\mathbf{P} 2 Y$ receptor agonists. (a) The mean amplitude of oscillating currents induced by ATP, UTP and UDP $\left(10^{-4} \mathrm{M}\right)$ was measured over successive $30 \mathrm{~s}$ intervals for 4 min in smooth muscle cells isolated from SPA and voltageclamped at $-50 \mathrm{mV} .0 .5=$ the first $30 \mathrm{~s}$ of agonist application, $\mathrm{I}=30-60 \mathrm{~s}$, and so on. (b) The frequency of the oscillations in the same cells was measured over successive I min intervals. I = the first min of agonist application, 2 = the second min, and so on. Vertical bars represent s.e.mean. The number of cells for each agonist is shown in parentheses. * $\mathrm{P}$ $<0.05$ for amplitude of peak current at $30 \mathrm{~s}$ versus that at 2:30, 3:00, 3:30 and 4:00 min; ** $P<0.0$ I for 30 s versus $3: 30$ and $4: 00 \mathrm{~min}$. min, apart from a small increase in the LPA between the first and second min after UTP application $(\mathrm{P}<0.05)$. The currents evoked by ATP in the first $30 \mathrm{~s}$ had a rise time of $1.7 \pm 0.3 \mathrm{~s}$ and width at $50 \%$ peak of $2.9 \pm 0.4 \mathrm{~s}(\mathrm{n}=4)$ in SPA and $1.5 \pm 0.6 \mathrm{~s}$ and $2.2 \pm 0.3 \mathrm{~s}(\mathrm{n}=5)$ respectively in LPA. The rise time and width at 50\% peak then decreased significantly $(\mathrm{P}<0.01)$ over the next $60-90$ s to a steady state of around $0.8 \mathrm{~s}$ in both SPA and LPA. The width at $50 \%$ peak of currents evoked by UTP in the first $30 \mathrm{~s}$ was $2.1 \pm 0.5 \mathrm{~s}(\mathrm{n}=5)$ in SPA and $2.1 \pm 0.5 \mathrm{~s}(\mathrm{n}=5)$ in LPA and both decreased significantly $(\mathrm{P}<0.01)$ over the next $60-90 \mathrm{~s}$ to a steady state of also about $0.8 \mathrm{~s}$. In contrast, currents evoked by UTP and UDP in SPA and LPA showed no significant change in rise time and those to UDP in SPA and LPA showed no significant change in width at $50 \%$ peak, all having a steady-state value of about $0.8 \mathrm{~s}$.

\section{Effects of $P 2$ receptor antagonists}

Having quantified the time-course of the agonist-induced oscillating currents, we then determined the effects of the P2Y antagonists suramin and PPADS $\left(10^{-4} \mathrm{M}\right)$. In most cells currents were initiated by an agonist, the antagonist was then coapplied and the currents compared for $1 \mathrm{~min}$ before and after antagonist addition. To take into account the decline in current amplitude normally seen over this time-course ( $20-40 \%)$, the \% decrease in amplitude over the 2 analysis periods was calculated and compared with that in control cells where agonist alone was added.

Suramin rapidly and reversibly abolished the currents evoked by ATP in SPA (Figure 4a, 5) and LPA (not shown). Additionally, ATP did not elicit currents if cells were preincubated with suramin for $5 \mathrm{~min}(\mathrm{n}=2$, not shown). In contrast, PPADS $\left(10^{-4} \mathrm{M}\right)$ had no effect on the amplitude or frequency of the ATP-induced currents in SPA (Figure $4 \mathrm{~b}, 5)$ or LPA (not shown). The rise-time and width at $50 \%$ peak were also unaffected (not shown). PPADS was also ineffective if applied for 5 min prior to ATP $(n=2)$. Neither suramin nor PPADS had any effect on the amplitude or frequency of the oscillating currents elicited by UTP or UDP in either SPA or LPA (Figure 4c,5). The risetime and width at 50\% peak were also unaffected (not shown). PPADS $(\mathrm{n}=12)$ and suramin $(\mathrm{n}=7)$ (Figure $4 d$ ) were also ineffective if applied for $5 \mathrm{~min}$ before UTP.

\section{Effects of suramin and PPADS on contractions evoked by ATP}

We have reported previously the effects of suramin and PPADS on contractions of rat pulmonary arteries induced by UTP and UDP [6]. Since suramin abolished current oscillations induced by ATP, but not UTP or UDP, we investigated if nucleotide-induced contractions showed the same differential sensitivity. We report that ATP $\left(10^{-7}\right.$ - $\left.3 \times 10^{-4} \mathrm{M}\right)$ evoked concentration-dependent contractions of the rat SPA (Figure 6). Suramin $\left(3 \times 10^{-5}-10^{-4} \mathrm{M}\right)$ 

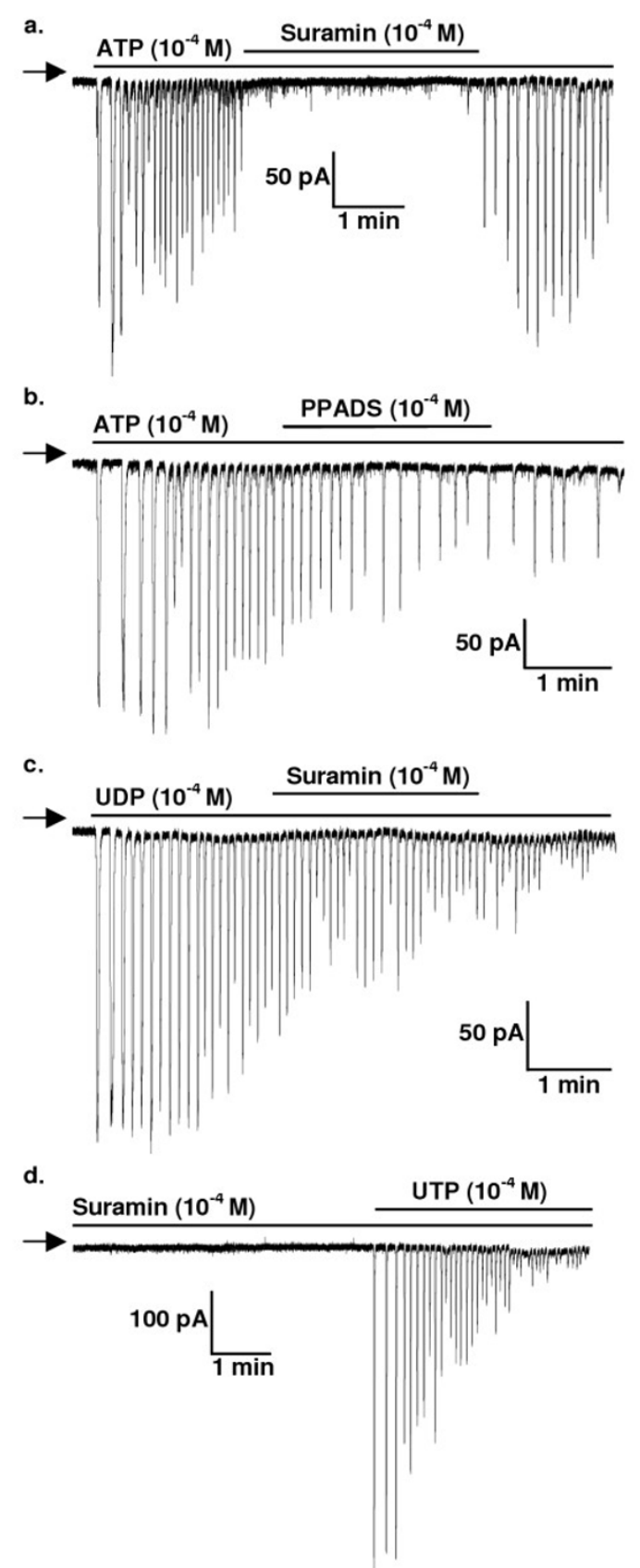

\section{Figure 4}

The effects of $P 2$ receptor antagonists on oscillating currents. The $\mathrm{P} 2$ receptor antagonists suramin and PPADS $\left(10^{-4} \mathrm{M}\right)$ were applied either $2 \mathrm{~min}$ after oscillations were induced by continuous application of $10^{-4} \mathrm{M}(\mathrm{a}, \mathrm{b})$ ATP or (c) UDP or (d) 5 min before application of 10-4 M UTP to SPA (a, b) or LPA (c, d) dissociated smooth muscle cells voltageclamped at $-50 \mathrm{mV}$. The horizontal bars indicate agonist and antagonist applications. The arrow on the left-hand side of each trace indicates zero holding current.
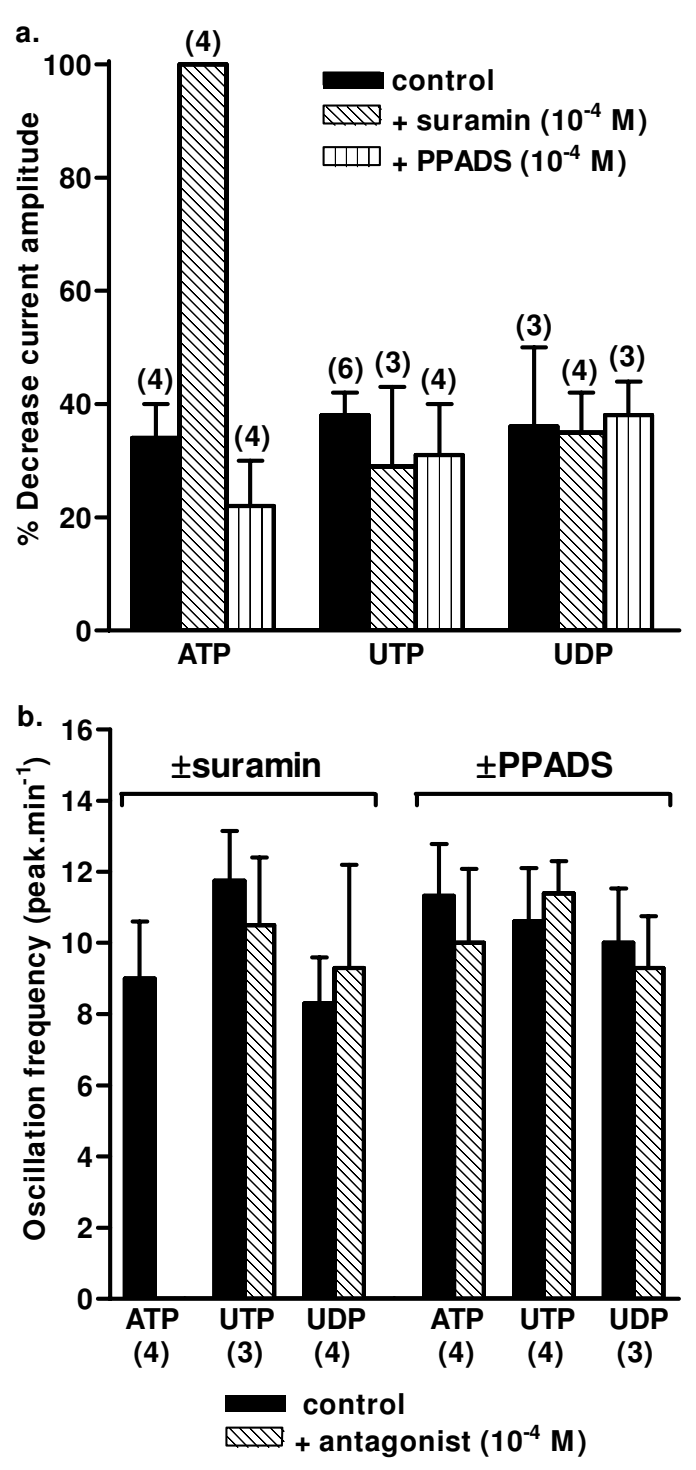

Figure 5

The effects of $P 2$ receptor antagonists on oscillating current amplitude and frequency. The effects of suramin and PPADS (10-4 M) on (a) the amplitude and (b) the frequency of oscillating inward currents induced by ATP, UTP and UDP $\left(10^{-4} \mathrm{M}\right)$ in SPA dissociated smooth muscle cells, voltage-clamped at $-50 \mathrm{mV}$, are shown. The agonist was applied for 2 min and then suramin or PPADS was coapplied for a further 2-3 min. The current amplitude was measured for I min immediately before and after antagonist addition and average values calculated. The $\%$ decrease in amplitude was then calculated as the difference in the 2 average values. The control data were obtained over the same time-course in cells where agonist alone was added. The average frequency of oscillations was also measured for I min immediately before and after antagonist addition and compared directly. Vertical lines show s.e.mean. The number of cells is shown in parentheses. 
caused a progressive rightward shift of the ATP concentration-response curve and the responses were abolished by the highest concentration of the antagonist (Figure 6a). PPADS $\left(3 \times 10^{-5} \mathrm{M}\right)$ also shifted the ATP concentrationresponse curve to the right, but increasing its concentration to $10^{-4} \mathrm{M}$ and $3 \times 10^{-4} \mathrm{M}$ ) produced no further inhibition (Figure 6b). In rat LPA ATP induced contractions only at $10^{-4} \mathrm{M}$ and above [6] and these small contractions were abolished by $3 \times 10^{-4} \mathrm{M}$ suramin or PPADS (not shown).

\section{Discussion}

The present study shows that ATP, UTP and UDP induce oscillating inward currents with similar amplitudes and frequencies in smooth muscle cells of rat pulmonary arteries. Such $\mathrm{Cl}^{-}$currents have been reported previously in these cells and are dependent upon nucleotide-evoked release of $\mathrm{Ca}^{2+}$ from sarcoplasmic reticulum stores $[4,5,26]$. The $\mathrm{P} 2 \mathrm{Y}_{1}, \mathrm{P} 2 \mathrm{Y}_{2}, \mathrm{P}_{2} \mathrm{Y}_{4}, \mathrm{P}_{2} \mathrm{Y}_{6}$ and $\mathrm{P} 2 \mathrm{Y}_{11}$ receptors all couple to the $\mathrm{G}_{\mathrm{q} / 11} \mathrm{G}$ proteins, leading to the release of $\mathrm{IP}_{3}$-sensitive $\mathrm{Ca}^{2+}$ stores [14] and so could, if present in the tissue, mediate activation of $\mathrm{I}_{\mathrm{Cl}, \mathrm{Ca}}$. UTP and UDP both acted at a site that was insensitive to the antagonists suramin and PPADS, which may be the $\mathrm{P} 2 \mathrm{Y}_{6}$ receptor or perhaps a novel receptor. ATP clearly acted via a different subtype, which most resembles the $\mathrm{P}_{2} \mathrm{Y}_{11}$ receptor. There were few differences apparent between the SPA and LPA, consistent with our previous conclusion from contractile studies that there is no regional variation in the $\mathrm{P} 2 \mathrm{Y}$ subtype distribution. Thus, multiple subtypes of P2Y receptor are widely expressed in pulmonary artery smooth muscle and are likely to play a role in nucleotide-induced vasoconstriction.

\section{$P 2 Y$ receptors in SPA and LPA}

In these experiments, the currents evoked by ATP in cells from the SPA and LPA were abolished by suramin, but unaffected by PPADS. ATP is an agonist at the P2 $\mathrm{Y}_{1,2,4} \& 11$ receptors [15] and the $\mathrm{P}_{2} \mathrm{Y}_{1}$ and $\mathrm{P}_{2} \mathrm{Y}_{4}$ subtypes can be ruled out, because PPADS antagonises both of these [4]. The $\mathrm{P} 2 \mathrm{Y}_{2}$ receptor can also be discounted as responses to the $\mathrm{P} 2 \mathrm{Y}_{2}$ agonist UTP were not inhibited by suramin. The remaining $\mathrm{P}_{2} \mathrm{Y}_{11}$ receptor is antagonised by suramin, but not PPADS [27], consistent with a role in mediating the ATP-induced $\mathrm{I}_{\mathrm{Cl}, \mathrm{Ca}}$. This is problematic, however, as the rat $\mathrm{P}_{2} \mathrm{Y}_{11}$ receptor has yet to be cloned. Indeed, it is not clear that it is present in the rodent genome, although a previous pharmacological study is also consistent with its expression in rat blood vessels [28]. Further studies are required to address this issue. Note that ATP has been reported to be an agonist at the $\mathrm{P}_{2} \mathrm{Y}_{12}$ receptor [29] and that a contractile $\mathrm{P} 2 \mathrm{Y}_{12}$ receptor was recently reported in human blood vessels [30]. However, the agonist action of ATP has been questioned [31] and the $\mathrm{P} \mathrm{Y}_{12}$ receptor couples to $G_{i}$ and so is unlikely to induce the release of $\mathrm{Ca}^{2+}$
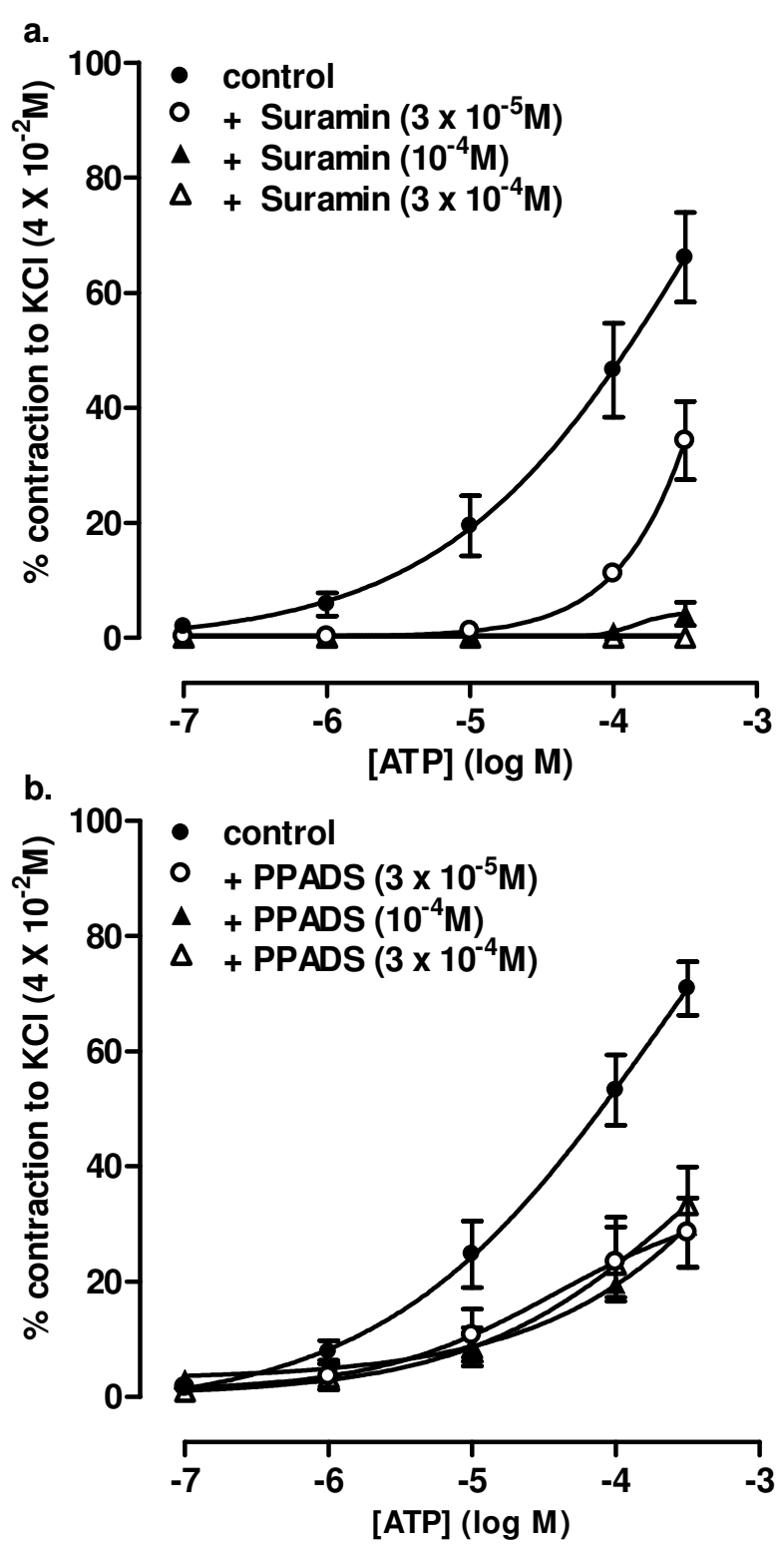

Figure 6

Effects of suramin and PPADS on contractions evoked by ATP. The effects of (a) suramin and (b) PPADS on contractions of rat isolated SPA induced by ATP are shown. Cumulative concentration-response curves to ATP $\left(10^{-7}-3 \times 10^{-4} \mathrm{M}\right)$ were obtained in rings in the absence of antagonist (control) or in the presence of $3 \times 10^{-5}, 10^{-4}$ or 3 $\times 10^{-4} \mathrm{M}$ of antagonist. Contractions are expressed as a percentage of the contraction induced by $4 \times 10^{-2} \mathrm{M} \mathrm{KCl}$. Vertical lines show s.e.mean. $n=5$ for suramin and 4 for PPADS. 
stores needed to activate $\mathrm{I}_{\mathrm{Cl}, \mathrm{Ca}}$ in rat pulmonary arteries [5].

UTP and UDP also activated $\mathrm{I}_{\mathrm{Cl}, \mathrm{Ca}}$, but the responses were unaffected by suramin or PPADS. This is consistent with the lack of effect of the antagonists on UTP- and UDPinduced vasoconstriction in the rat perfused pulmonary vascular bed [10] and with the antagonist-insensitive component of UTP and UDP contraction of isolated pulmonary artery [6], but contrasts with the abolition by suramin of UTP-elicited oscillating currents seen previously in single cells $[5,12]$. The reason for these differences in suramin activity is not clear. Which receptor(s) mediated the actions of UTP and UDP in the present study is also unclear. UTP is an agonist at the $\mathrm{P} 2 \mathrm{Y}_{2^{\prime} 4} \&_{6}$ subtypes, whilst UDP is only active at the $\mathrm{P}_{2} \mathrm{Y}_{6}$ receptor $[2,15]$. Detailed studies show clearly that the $\mathrm{P}_{2} \mathrm{Y}_{2}$ receptor is antagonised by suramin and the $\mathrm{P}_{2} \mathrm{Y}_{4}$ receptor by PPADS $(2,20)$. So, these subtypes do not mediate the effects of UTP (or UDP) seen here.

If the $\mathrm{P} 2 \mathrm{Y}_{2}$ and $\mathrm{P} 2 \mathrm{Y}_{4}$ receptors are ruled out, then the $\mathrm{P} 2 \mathrm{Y}_{6}$ receptor is the prime candidate for the site of action of UTP and UDP. Indeed, its mRNA is present in rat pulmonary artery smooth muscle and it has been proposed to underlie the UDP-induced $\mathrm{I}_{\mathrm{Cl}, \mathrm{Ca}}[12]$. However, the effects of suramin and PPADS at this site are not well characterised. In the only study on the cloned rat $\mathrm{P}_{2} \mathrm{Y}_{6}$ receptor, $10^{-4} \mathrm{M}$ suramin (the same concentration used in the present study) depressed the agonist response by $20 \%$ [32]. Similar inhibition (27\%) was seen at the cloned human $\mathrm{P}_{2} \mathrm{Y}_{6}$ receptor [18]. PPADS was not tested at the rat receptor, but at $10^{-4} \mathrm{M}$ it inhibited the response to UDP at the human subtype by $69 \%$. This pronounced effect of PPADS is inconsistent with the $\mathrm{P}_{2} \mathrm{Y}_{6}$ receptor being the receptor through which $U T P$ and UDP activated $\mathrm{I}_{\mathrm{Cl}, \mathrm{Ca}}$ in the present study. Further characterisation of the effects of suramin and PPADS at the recombinant rat $\mathrm{P}_{2} \mathrm{Y}_{6}$ receptor is, however, needed to substantiate this conclusion.

If the $\mathrm{P} 2 \mathrm{Y}_{2}, \mathrm{P} 2 \mathrm{Y}_{4}$ and $\mathrm{P} 2 \mathrm{Y}_{6}$ receptors are not the site(s) of action of UTP and UDP, then what is? One possibility is that UTP and UDP activated $\mathrm{I}_{\mathrm{Cl}, \mathrm{Ca}}$ in rat SPA and LPA smooth muscle via a novel, as yet uncloned $\mathrm{P} 2 \mathrm{Y}$ receptor or another, non-P2Y receptor. For example, UDP has been proposed to interact with cysteinyl leukotriene receptors in human mast cells [33,34]. Alternatively, one of the known P2Y receptors may interact with another P2Y subtype, or with a non-P2Y receptor, to form a dimer with novel pharmacological properties. Indeed, the $\mathrm{P}_{2} \mathrm{Y}_{1}$ and $\mathrm{P} 2 \mathrm{Y}_{2}$ receptors both appear to form dimers with the A1 adenosine receptor [35]. Further studies are needed to investigate these possibilities.

\section{P2X receptors in SPA and LPA}

In this study, the currents evoked by ATP, UTP and UDP had similar time-courses, as measured by rise time and width at 50\% peak. This may appear surprising as ATP, but not UTP or UDP, is also an agonist at the $\mathrm{P}_{2} \mathrm{X}_{1}$ receptor and so might be expected to activate an initial, rapid, transient inward current, in addition to the slower, longer lasting, P2Y-mediated oscillations, as has been reported previously in rat pulmonary artery smooth muscle cells $[4,5]$. The apparent absence of the transient response may be due to the relatively slow speed of application of ATP used here. The $\mathrm{P} 2 \mathrm{X}_{1}$ receptor desensitizes rapidly and slow agonist administration elicits much slower and smaller currents in vascular smooth muscle cells [36]. Although this would be disadvantageous if studying P2X receptors, by minimizing the $\mathrm{P} 2 \mathrm{X}$ response it is in fact an advantage when P2Y receptors are under study. The initial current evoked by ATP in SPA and LPA may well be a mixture of $\mathrm{P}_{2} \mathrm{X}_{1}$ and $\mathrm{P} 2 \mathrm{Y}$ receptor-induced responses, which would explain the larger amplitude of the initial ATP-induced current, compared with UTP and UDP. Nevertheless, any $\mathrm{P}_{2} \mathrm{X}_{1}$ component appears to play a relatively minor role and would not contribute to the sustained phase of oscillations.

\section{Contribution of P2Y subtypes to contractions}

Although the receptors that mediate activation of $\mathrm{I}_{\mathrm{Cl} \text {, } \mathrm{Ca}}$ by nucleotides in the rat pulmonary artery have not been identified unequivocally, we can still consider their role in vasoconstriction of the rat pulmonary vascular bed [10] and isolated arteries $[6,12,13]$. In this study, contractions of the SPA elicited by ATP were abolished by suramin, but only partially inhibited by PPADS. The PPADS-resistant contractions likely reflect release of $\mathrm{Ca}^{2+}$ stores, causing the $\mathrm{I}_{\mathrm{Cl}, \mathrm{Ca}}$ recorded here. They may also involve $\mathrm{Ca}^{2+}$ influx via L-type $\mathrm{Ca}^{2+}$ channels, opened by depolarisation due to $\mathrm{I}_{\mathrm{Cl}, \mathrm{Ca}}$. Further experiments using channel blockers are needed to confirm this. The $\mathrm{P} 2 \mathrm{X}_{1}$ receptor in SPA smooth muscle [6] is most likely to underlie the remaining suramin- and PPADS-sensitive component. Interestingly, contractions of the rat LPA were abolished by both suramin and PPADS, suggesting that only one receptor, probably the $\mathrm{P} 2 \mathrm{X}_{1}$ receptor, mediates the contractile actions of ATP here. This is consistent with the much lower contractile potency of ATP in LPA [6], but it suggests that the similar suramin- and PPADS-insensitive $\mathrm{I}_{\mathrm{Cl}, \mathrm{Ca}}$ observed in response to ATP in LPA and SPA may serve different functions. In our previous study [6] contractions of rat SPA induced by UTP and UDP were not inhibited by PPADS and were only partially suppressed by suramin. These antagonist-resistant contractions again likely reflect release of $\mathrm{Ca}^{2+}$ stores and activation of $\mathrm{I}_{\mathrm{Cl}, \mathrm{Ca}}$. The identity of the suramin-sensitive receptors remains to be determined. 


\section{Advantages of the patch clamp technique}

This study shows that recording ion currents in single cells can be useful in characterising the receptors expressed in tissues where multiple subtypes are present. A particular problem with P2Y receptors is ecto-nucleotidases, which are inhibited by PPADS in smooth muscle [37] and other tissues $[38,39]$. Recording from rapidly perfused, single cells minimises the problems created by extracellular metabolism in whole tissues, which may explain why PPADS potentiated contractions to UTP and UDP in the intact artery [6], but had no effect on activation of $\mathrm{I}_{\mathrm{Cl}, \mathrm{Ca}}$ in single cells. Such studies also allow the regional variation in ion channel expression to be studied. Interestingly, we recorded $\mathrm{I}_{\mathrm{Cl}, \mathrm{Ca}}$ in a similar proportion of rat SPA and LPA smooth muscle cells, whereas in rabbits it is more predominant in smaller pulmonary arteries [25]. Limitations of the patch clamp technique encountered here were short recording times, wide variation in current amplitude between cells and a decline in the amplitude of $\mathrm{I}_{\mathrm{Cl}, \mathrm{Ca}}$ over the recording period, all of which hampered quantitative analysis of antagonist action. It is not clear why rundown occurred, as loss of diffusible cytosolic factors into the recording pipette should have been minimised with the perforated-patch technique. Similar rundown was seen in previous patch clamp studies in these cells $[4,5]$ and with ATP- and UTP-induced oscillations in cytosolic [ $\left.\mathrm{Ca}^{2+}\right]$ [26]. Thus, the decline in $\mathrm{I}_{\mathrm{Cl}, \mathrm{Ca}}$ may in fact reflect a physiological mechanism of signalling whereby the P2Y receptors become desensitised and/or intracellular stores release progressively less $\mathrm{Ca}^{2+}$ during maintained activation of P2Y receptors.

\section{Conclusion}

The results of the present study indicate the presence of at least two different subtypes of P2Y receptors mediating oscillating inward currents in rat SPA and LPA smooth muscle cells. ATP acts via a suramin-sensitive, PPADSinsensitive site, which most resembles the $\mathrm{P}_{2} \mathrm{Y}_{11}$ receptor. The site of action of UTP and UDP is less clear. Its pharmacology is inconsistent with our present understanding of $\mathrm{P} 2 \mathrm{Y}_{2,4} \& 6$ receptors, so a novel receptor or receptor complex may be involved. These different $\mathrm{P} 2 \mathrm{Y}$ receptors are likely to play a significant role in nucleotide-induced pulmonary vasoconstriction as ATP, UTP and UDP each induce contractions of the rat pulmonary artery with matching pharmacological profiles.

\section{Competing interests}

The author(s) declare that they have no competing interests.

\section{Authors' contributions}

$\mathrm{KC}$ was involved in the planning of the experiments described and carried them out. She also analysed the data, drafted the manuscript and was involved in its revi- sion. AMG was involved in the planning of the experiments and revision of the manuscript. CK was involved in the planning of the experiments, the analysis of the data and revision of the manuscript. All authors read and approved the final manuscript.

\section{Acknowledgements}

This work was supported by funding from the Faculty of Medical Science, Naresuan University, Thailand and The Royal Society of Edinburgh.

\section{References}

I. Burnstock G, Kennedy C: A dual function for adenosine triphosphate in the regulation of vascular tone: excitatory cotransmitter with noradrenaline from perivascular nerves and locally released inhibitory intravascular agent. Circ Res 1986, 58:319-330.

2. Boarder MR, Hourani MO: The regulation of vascular function by $\mathbf{P} 2$ receptors: multiple sites and multiple receptors. Trends Pharmacol Sci 1998, 19:99-107.

3. Ralevic $V$, Burnstock $G$ : Receptors for purines and pyrimidines. Pharmacol Rev 1998, 50:413-49|.

4. Bakhramov A, Hartley SA, Salter KJ, Kozlowski RZ: Contractile agonists preferentially activate $\mathrm{Cl}^{-}$over $\mathrm{K}^{+}$currents in arterial myocytes. Biochem Biophys Res Comm 1996, 227:168-175.

5. Hartley SA, Kozlowski RZ: Electrophysiological consequences of purinergic receptor stimulation in isolated rat pulmonary arterial myocytes. Circ Res 1997, 80:170-178.

6. Chootip K, Ness KF, Wang Y, Gurney AM, Kennedy C: Regional variation in $\mathbf{P 2}$ receptor expression in the rat pulmonary arterial circulation. BrJ Pharmacol 2002, 137:637-646.

7. Mc Cormack DG, Barnes PJ, Evans TW: Purinoceptors in the pulmonary circulation of the rat and their role in hypoxic vasoconstriction. BrJ Pharmacol 1989, 98:367-372.

8. Barnes PJ, Liu SF: Regulation of pulmonary vascular tone. Pharmacol Rev 1995, 47:87-131.

9. Hasséssian H, Burnstock G: Interacting roles of nitric oxide and ATP in the pulmonary circulation of the rat. $\mathrm{Br} J$ Pharmacol 1995, I 1 4:846-850.

10. Rubino $A$, Burnstock G: Evidence for a $\mathbf{P}_{2}$ purinoceptor mediator mediation vasoconstriction by UTP, ATP and related nucleotides in the isolated pulmonary vascular bed of the rat. Br J Pharmacol 1996, I I 8: I4I5-1420.

II. Liu SF, Mc Cormack DG, Evans TW, Barnes PJ: Characterization and distribution of $\mathbf{P}_{2}$-purinoceptor subtypes in rat pulmonary vessels. J Pharmacol Exp Ther 1989, 25 I: I 204-I2 I0.

12. Hartley SA, Kato K, Salter KJ, Kozlowski RZ: Functional evidence for a novel suramin-insensitive pyrimidine receptor in rat small pulmonary arteries. Circ Res 1998, 83:940-946.

13. Rubino A, Ziabary L, Burnstock G: Regulation of vascular tone by UTP and UDP in isolated rat intrapulmonary arteries. Eur J Pharmacol 1999, 370:139-143.

14. Boarder MR, Webb TE: P2Y receptors: structure and function. In Handbook of Experimental Pharmacology 151/I; Purinergic and Pyrimidinergic Signalling I: Molecular, Nervous and Urogenitary System Function Edited by: Abbracchio MP, Williams M. Springer; 2001:65-88.

15. Abbracchio MP, Boeynaems JM, Barnard EA, Boyer JL, Kennedy C, Miras-Portugal M, King BF, Gachet C, Jacobson KA, Weisman GA, Burnstock G: Characterization of the UDP-glucose receptor (re-named here the $\mathrm{P}_{2} \mathrm{Y}_{14}$ receptor) adds diversity to the P2Y receptor family. Trends Pharmacol Sci 2003, 24:52-55.

16. Nicholas RA, Watt WC, Lazarowski ER, Li Q, Harden TK: Uridine nucleotide selectivity of three phospholipase C-activating P2 receptors: Identification of a UDP-selective, a UTP-selective, and an ATP- and UTP-specific receptor. Mol Pharmacol 1996, 50:224-229.

17. Filippov AK, Webb TE, Barnard EA, Brown DA: Dual coupling of heterologously-expressed rat $\mathrm{P}_{2} \mathrm{Y}_{6}$ nucleotide receptors to $\mathrm{N}$-type $\mathrm{Ca}^{2+}$ and $\mathrm{M}$-type $\mathrm{K}^{+}$currents in rat sympathetic neurones. Br J Pharmacol 1999, I 26:1009-1017.

18. Robaye B, Boeynaems JM, Communi D: Slow desensitization of the human P2Y 6 receptor. Eur J Pharmacol 1997, 329:23I-236. 
19. Bogdanov YD, Wildman SS, Clements MP, King BF, Burnstock G: Molecular cloning and characterisation of rat $\mathrm{P}^{2} \mathrm{Y}_{4}$ nucleotide receptor. BrJ Pharmacol 1988, I 24:428-439.

20. Suarez-Huerta N, Pouillon V, Boeynaems JM, Robaye B: Molecular cloning and characterization of the mouse $\mathrm{P}_{2} \mathrm{Y}_{4}$ nucleotide receptor. Eur J Pharmacol 200I, 4 I6: 197-202.

21. Kennedy C, Leff P: How should P2X-purinoceptors be characterised pharmacologically? Trends Pharmacol Sci 1995, 16:168-174.

22. Lazarowski ER, Boucher RC, Harden TK: Constitutive release of ATP and evidence for major contribution of ecto-nucleotide pyrophosphatase and nucleoside diphosphokinase to extracellular nucleotide concentrations. J Biol Chem 2000, 275:31061-31068.

23. Lazarowski ER, Boucher RC, Harden TK: Mechanisms of release of nucleotides and integration of their actions as P2X-and P2Y-receptor activating molecules. Mol Pharmacol 2003, 64:785-795.

24. Zimmermann H: Extracellular metabolism of ATP and other nucleotides. Naunyn-Schmied Arch Pharmacol 2000, 362:299-309.

25. Smani T, Iwabuchi S, López-Barneo J, Ureña J: Differential segmental activation of $\mathrm{Ca}^{2+}$-dependent $\mathrm{Cl}$ and $\mathrm{K}^{+}$channels in pulmonary arterial myocytes. Cell Calcium 200I, 29:369-377.

26. Guibert C, Pacaud P, Loirand G: Effect of extracellular ATP on cytosolic $\mathrm{Ca}^{2+}$ concentration in rat pulmonary artery myocytes. Am J Physiol 1996, 27 I:L450-L458.

27. Communi D, Robaye B, Boeynaems JM: Pharmacological characterization of the human $\mathrm{P}_{2} \mathbf{Y}_{11}$ receptor. Br J Pharmacol 1999 , I 28: I 199-1206.

28. Gitlin JM, Zanesco A, Stanford SJ, Evans TW, Anning PB, Mitchell JA: The second phase of ATP mediated relaxation is mediated through $\mathrm{P2Y}_{11}$ receptors. BrJ Pharmacol 2002, I35:2 IOP.

29. Takasaki J, Kamohara M, Saito T, Matsumoto M, Matsumoto SI, Ohishi $\mathrm{T}$, Soga T, Matsushime H, Furuichi K: Molecular cloning of the platelet P2T $_{A C}$ ADP receptor: pharmacological comparison with another ADP receptor, the $\mathbf{P 2} Y_{1}$ receptor. Mol Pharmacol 200I, 60:432-439.

30. Wihlborg AK, Wang L, Braun OO, Eyjolfsson A, Gustafsson R, Gudbjartsson T, Erlinge D: ADP receptor P2Y 12 is expressed in vascular smooth muscle cells and stimulates contraction in human blood vessels. Arterioscler Thromb Vasc Biol 2005, 24: I-7.

31. Kauffenstein G, Hechler B, Cazenave JP, Gachet C: Adenosine triphosphate nucleotides are antagonists at the $P 2 Y_{12}$ receptor. J Thromb Haem 2004, 2:980-1988.

32. Chang K, Hanaoka K, Kumada M, Takuwa $Y$ : Molecular cloning and functional analysis of a novel P2 nucleotide receptor. J Biol Chem 1995, 270:26152-26I58.

33. Mellor EA, Maekawa A, Austen KF, Boyce JA: Cysteinyl leukotriene receptor $I$ is also a pyrimidergic receptor and is expressed by human mast cells. Proc Natl Acad Sci USA 200I, 98:7964-7969.

34. Mellor EA, Austen KF, Boyce JA: Cysteinyl leukotrienes and uridine diphosphate induce cytokine generation by human mast cells through an interleukin 4-regulated pathway that is inhibited by leukotrienne receptor antagonists. J Exp Med 2002, 195:583-592.

35. Yoshioka $\mathrm{K}$, Saitoh $\mathrm{O}, \mathrm{Nakata} \mathrm{H}$ : Heteromeric association creates a P2Y-like adenosine receptor. Proc Natl Acad Sci USA 200I, 98:7617-7622.

36. Evans RJ, Kennedy C: Characterisation of P2-purinoceptors in the smooth muscle of the rat tail artery: a comparison between contractile and electrophysiological responses. $\mathrm{Br}$ Pharmacol 1994, I I 3:853-860.

37. Khakh BS, Michel AD, Humphrey PPA: Inhibition of ectoATPase and Ca-ATPase in rat vas deferens by $P_{2}$-purinoceptor antagonists. Br J Pharmacol 1995, I I 5:2P.

38. Chen BC, Lee CM, Lin WW: Inhibition of ecto-ATPase by PPADS, suramin and reactive blue in endothelial cells, $\mathrm{C} 6$ glioma cells and RAW 264.7 macrophages. Br J Pharmacol I996, I 19:1628-1634.

39. Grobben B, Claes P, Roymans D, Esmans EL, Van Onckelen H, Slegers $\mathrm{H}$ : Ecto-nucleotide pyrophosphatase modulates the purinoceptor-mediated signal transduction and is inhibited by purinoceptor antagonists. BrJ Pharmacol 2000, I 30:| $39-145$.
Publish with Bio Med Central and every scientist can read your work free of charge

"BioMed Central will be the most significant development for disseminating the results of biomedical research in our lifetime. "

Sir Paul Nurse, Cancer Research UK

Your research papers will be:

- available free of charge to the entire biomedical community

- peer reviewed and published immediately upon acceptance

- cited in PubMed and archived on PubMed Central

- yours - you keep the copyright

Submit your manuscript here:

http://www.biomedcentral.com/info/publishing_adv.asp
BiolMedcentral 